AL-MUDARRIS : journal of education, Vol. 2, No. 1 April 2019

Homepage

ISSN : http://e-journal.staima-alhikam.ac.id/index.php/al-mudarris

DOI : 2620-5831 (print), ISSN: 2620-4355(online)

Article type : 10.32478/al-mudarris.v2i1.227

: Original Research Article

\title{
HYBRID LEARNING DALAM PEMBELAJARAN KOSA KATA BAHASA ARAB PADA ANAK BERBANTUAN MEDIA AL-MUTHO
}

\section{Nuril Mufidah*1, Umi Salamah*2, Imroatul Muthoharoh*3, M. Irfan Islamy*4}

${ }^{1,3,4}$ FITK, Universitas Islam Negeri Maulana Malik Ibrahim Malang, Indonesia, ${ }^{2}$ PGMI, STAI Ma'had Aly Al-Hikam Malang, Indonesia ${ }^{1}$ nurilmufidah86@uin-malang.ac.id, 2umisalamah393@gmail.com 3imroatulmuthoharoh21@gmail.com, ${ }^{3}$ irfan.islamy87@uinmalang.ac.id

\begin{abstract}
This study aims to develop learning media in the form of videos called "Al-Mutho" videos on Haalatul Hadiiqoh material in third-grade students of elementary school. This is qualitative descriptive research and type of case study that aims to determine students' perceptions in using 'AlMutho" videos. The results showed that students felt happier and eager to learn vocabulary (mufrodat) by using the video "Al-Mutho." Also, students are also able to remember ten new vocabulary words that are taught in one time face to face. This can be seen from the ability of students to answer the questions given quickly and precisely. Based on the results of the study it can be concluded that the video "Al-Mutho" can be used as an alternative media for mufrodat learning in Arabic for elementary schools.
\end{abstract}

Keywords: Media, Al-Mutho Videos, Vocabulary

\section{Abstrak}

Penelitian ini bertujuan untuk mengembangkan media pembelajaran dalam bentuk video yang disebut dengan

40 E-mail address: nurilmufidah86@uin-malang.ac.id, umisalamah393@gmail.com imroatulmuthoharoh21@gmail.com, irfan.islamy87@uin-malang.ac.id Peer reviewed under reponsibility of STAI Ma'had Aly Al-Hikam Malang C2019 STAI Ma'had Aly Al-Hikam Malang, All right reserved, This is an open access article under 
AL-MUDARRIS:journal of education, Vol. 2. No. 1 April 2019, ISSN: 2620-5831 (print), ISSN: 2620-4355(online)

DOI: $10.32478 /$ al-mudarris.v2i1.227

video "Al-Mutho" pada materi Haalatul Hadiiqoh pada siswa kelas III Madrasah Ibtidaiyah. Metode penelitian deskriptif kualitatif jenis studi kasus yang bertujuan untuk mengetahui persepsi siswa dalam penggunaan video 'AlMutho". Hasil penelitian menunjukkan bahwa siswa merasa lebih senang dan bersemangat dalam belajar mufrodat dengan menggunakan video "Al-Mutho". Selain itu siswa juga mampu mengingat 10 kosa kata baru yang diajarkan dalam waktu satu kali tatap muka. Hal ini terlihat dari kemampuan siswa menjawab pertanyaan-pertanyaan yang diberikan secara cepat dan tepat. Berdasarkan hasil penelitian dapat disimpulkan bahwa video "Al-Mutho" dapat dijadikan alternatif media pembelajaran mufrodat dalam Bahasa Arab untuk Madrasah Ibtidaiyah.

Kata Kunci: Media, Video Al-Mutho, Mufrodat

\section{A. PENDAHULUAN}

Bahasa merupakan simbol untuk pengungkapan dalam berkomunikasi. Setiap komunikasi memiliki tujuan, baik tersurat maupun tersirat. Keinginan, harapan, emosi, bahagia dan sebagainya dapat diungkapkan melalui simbolsimbol yang diciptakan oleh individu manusia untuk diketahui dan dipahami oleh orang lain. ${ }^{1}$ Sejak lahir anak sudah mengenal dan familiar dengan bahasa ibu, karena setiap hari yang didengarkan adalah bahasa ibu sebagai bahasa pertama. Selain bahasa ibu anak juga perlu mengenal bahasa kedua, salah satunya bahasa arab. Karena bahasa arab merupakan bahasa yang sangat penting untuk dipelajari. Bahasa arab tidak hanya dipergunakan untuk manusia, tapi juga bahasa pilihan Allah yang dipergunakan untuk ibadah antara Allah dan hamba-Nya. ${ }^{2}$

\footnotetext{
${ }^{1}$ Nur Kholis, Budaya Berbahasa Asing di SD Laboratorium Universitas Negeri Malang Kota Blitar, Journal AL-MUDARRIS, 1.1 (2018), 1 <https://doi.org/10.32478/al-mudarris.v1i1.92>.

${ }^{2}$ Ismail Suardi Wekke, Model Pembelajaran Bahasa Arab (Yogyakarta: Deepublish (Group Penerbitan CV Budi Utama), 2015).
} 
DOI:

Mempelajari bahasa arab sebagai bahasa kedua tidak semudah mempelajari bahasa ibu, karena bukan bahasa keseharian anak. Bahasa arab termasuk bahasa asing/ bahasa kedua yang harus dipelajari siswa MI selain bahasa Inggris. Selama ini siswa merasa kesulitan untuk mempelajari dan menghafal kosa kata bahasa arab. Perlu model, metode, dan media yang sesuai untuk membantu proses mengajarkannya. Dengan sarana yang tepat, anak akan merasa senang dan tertarik mempelajari bahasa arab.

Beberapa penelitian terdahulu yang sudah meneliti tentang mempelajari bahasa arab antara lain, Pembelajaran Kooperatif Tipe Make A Match Dalam Meningkatkan Penguasaan Kosa Kata Bahasa Arab Santri TPA AlBarokah Hadimulyo Timur Metro Pusat. Tujuan dari penelitian ini secara umum adalah meningkatkan hasil penguasaan kosakata siswa Arab dengan model pendekatan kooperatif untuk membuat kecocokan. Penelitian ini menggunakan desain penelitian tindakan kelas. Subjek dalam penelitian ini adalah siswa anak usia sekolah dasar dan SMP TPA (7-12 tahun). Hasil penerapan pembelajaran dengan jenis kosa kata metode pembelajaran kooperatif membuat kecocokan untuk menyebutkan bahwa, ada peningkatan dalam hasil belajar yang terkait dengan penguasaan kosakata bahasa Arab. ${ }^{3}$

Optimalisasi Aplikasi Busuu Dalam Pembelajaran Bahasa Arab Mandiri, aplikasi Busuu merupakan media daring untuk pembelajaran bahasa Asing mandiri yang telah populer di berbagai belahan dunia. Aplikasi ini memiliki fitur gratis dan berbayar. Penggunaan aplikasi Busuu dalam belajar bahasa Arab akan mendapat hasil maksimal apabila pengguna menggunakan fitur berbayar, sedangkan fitur gratis hanya memberikan layanan belajar bahasa Arab yang tidak maksimal. Namun penggunaan aplikasi ini juga sangat menunjang dan membuka wawasan baru untuk berinovasi dalam belajar dan mengajar bahasa Arab. Aplikasi ini membuat pengguna senang dan merasa nyaman dalam

\footnotetext{
${ }^{3}$ Muhammad Syaifullah, 'Penguasaan Kosa Kata Bahasa Arab Santri
} TPA Al-Barokah Hadimulyo Timur Metro Pusat', 11.2. 
AL-MUDARRIS:journal of education, Vol. 2. No. 1 April 2019, ISSN: 2620-5831 (print), ISSN: 2620-4355(online)

DOI: $10.32478 / a l-m u d a r r i s . v 2 i 1.227$

mempelajari Arab. Aplikasi Busuu juga memberikan kemudahan dalam belajar berbahasa Arab komunikatif secara mandiri. Implikasinya di masa yang akan datang, penguasaan bahasa Arab tidak hanya menjadi keniscayaan milik alumni madrasah ataupun pesantren. Semua individu berpotensi untuk menguasai bahasa Arab dengan kemajuan teknologi sehingga daya saing akan semakin tinggi dan akan menjadi motivasi tinggi untuk menguasai bahasa Arab. ${ }^{4}$

Berbeda dengan penelitian sebelumnya, penelitian ini bertujuan untuk mendeskripsikan penyiapan dan penggunaan video sebagai media pengajaran bahasa Arab untuk siswa. Selain itu juga untuk mengetahui persepsi siswa dalam mengingat mufrodat melalui video "AlMutho". Hasil penelitian ini bermanfaat untuk pengajar bahasa Arab tingkat pendidikan dasar dalam memilih dan menyiapkan media belajar yang sesuai untuk siswa.

\section{B. KAJIAN TEORI}

Dalam bahasa arab terdapat 3 unsur bahasa yaitu mufrodat, ashwat dan qowaid. ${ }^{5}$ Mufrodat merupakan lafadz atau kata yang terdiri dari dua huruf atau lebih yang menunjukkan makna dari pekerjaan, atau nama, atau alat. ${ }^{6}$ Mufrodat biasanya dipelajari di berbagai tingkatan sekolah, mulai dari madrasah Ibtidaiyah hingga Madrasah Aliyah atau tingkat mutaqoddim. Namun dalam tingkat mubtadi' atau Madrasah Ibtidaiyah sering dijumpai kesulitan dalam pembelajaran mufrodat khususnya pada taraf mengingat terutama di Madrasah Ibtidaiyah Karangdowo. Kesulitan ini tidak hanya terkait dengan pembelajaran atau teknik yang

\footnotetext{
${ }^{4}$ Azkia Muharom Albantani and others, 'OPTIMALISASI
}

APLIKASI BUSUU Arabi : Journal of Arabic Studies', 3.1 (2018), 1-10.

${ }^{5}$ Riza Izzatun Nisa', 'Istikhdaamul Wasaailus Sam'iyyatul

Bashoriyyatu “Audio Visual” Litarqiyati Isti'aabil Mufrodaatil 'Arobiyyati Fil Madrosati Miftahul 'Ulum Al-Ibtidaiyah Al-Islamiyah Pasuruan', Skripsi, 2017, 1-102.

${ }^{6}$ Wahyuddin, 'Ta'limul Lughotil Arobiyyati Bi Thoriiqoti Ta'liimil Mufrodaati (Diroosatun Washfiyyatun Taqwiimiyyatun Fii Jaami'isy Syaikh Nur Jati Al-Islaamiyyati Al-Hukuumiyyati Cirebon', 2012, pp. 1-152. 
AL-MUDARRIS:journal of education, Vol. 2. No. 1 April 2019, ISSN: 2620-5831 (print), ISSN: 2620-4355(online)

DOI:

guru lakukan, tetapi ada beberapa penyebab yang mempengaruhi pembelajaran mufrodat. Ada beberapa hal yang menjadi penyebab kesulitan siswa mengingat mufrodat yang diajarkan, diantaranya adalah: 1) kurangnya pemahaman materi, 2) penggunaan metode yang kurang tepat, 3) media yang kurang menarik atau proses belajar mengajar yang kurang bervariatif. ${ }^{7}$

Dalam penelitian ini, peneliti memanfaatkan teknologi yang mana saat ini teknologi sangat berperan aktif dalam kehidupan manusia, terutama pada bidang pendidikan. ${ }^{8}$ Dalam penelitian ini peneliti memanfaatkan teknologi komputer untuk membuat media video "AlMutho" karena beberapa alasan yaitu: 1) mudah dikemas, 2) lebih menarik untuk pembelajaran, 3) dapat diedit atau diperbaiki semenunjukkan tiap saat. ${ }^{9}$ Jadi, media video bukan hanya gambar atau peta konsep semata. Namun dalam media video "Al-Mutho" terdapat gambar sekaligus suara yang digabungkan sehingga akan menarik peserta didik, khususnya peserta didik Madrasah Ibtidaiyah Karangdowo karena di sekolah tersebut masih jarang sekali guru yang menggukan media video. Diharapkan setelah media video "Al-Mutho" ini dibuat dan digunakan oleh guru, hasil belajar mufrodat peserta didik akan meningkat.

Media adalah sarana atau alat yang digunakan oleh sumber pesan untuk menyampaikan pesan atau informasi belajar kepada sasaran atau penerima pesan tersebut. ${ }^{10}$ Dalam definisi lain media diartikan sebagai sesuatu yang dapat berisi informasi dan pengetahuan dalam interaksi

${ }^{7}$ Arif Wahyudi, Suhartono, and Ngatman, 'Penggunaan Media Audio Visual', Jurnal Penelitian Pendidikan, 2003.

${ }^{8}$ Devira Wiena Pramintya, Darlis Herumurti, and Anny Yuniarti, 'Realitas Virtual Untuk Belajar Kosa Kata Bahasa Cardboard', 6.2 (2017), 402-7.

${ }^{9}$ Sapto Haryoko, 'Efektivitas Pemanfaatan Media Audio-Visual Sebagai Alternatif Optimalisasi Model Pembelajaran', Jurnal Edukasi@Elektro, 5.1 (2010), 1-10.

${ }^{10}$ Oleh Nunu Mahnun, 'MEDIA PEMBELAJARAN ( Kajian Terhadap Langkah-Langkah Pemilihan Media Dan Implementasinya Dalam Pembelajaran )', 37.1 (2012). 
AL-MUDARRIS:journal of education, Vol. 2. No. 1 April 2019, ISSN: 2620-5831 (print), ISSN: 2620-4355(online)

DOI: $10.32478 /$ al-mudarris.v2i1.227

yang berlangsung antara pendidik dan peserta didik (Fathurrohman dan Sutekno, 2010). ${ }^{11}$

\section{METODE PENELITIAN}

Penelitian dilakukan di kelas III Madrasah Ibtidaiyah Karangdowo, Malang. Metode yang digunakan adalah metode penelitian deskriptif kualitatif yaitu suatu penelitian yang secara mendasar bergantung pada pandangan terhadap manusia dalam keadaannya sendiri dan berhubungan dengan orang-orang tersebutdalam peristilahannya dan bahasanya. ${ }^{12}$

Teknik pengumpulan data dalam penelitian ini yaitu dengan observasi dan wawancara. Observasi ${ }^{13}{ }^{14}$ untuk memperoleh data proses pembelajaran dengan menggunakan video "Al-Mutho" disamping untuk mendapatkan data persepsi siswa dalam mengikuti pembelajaran yang dilihat dari ekspresi dan keaktifan siswa. Sedang wawancara untuk memperoleh data persepsi siswa yang berkaitan dengan motivasi dan minat siswa dalam proses pembelajaran.

Teknik wawancara dan observasi dalam penelitian ini dilakukan oleh peneliti terhadap siswa kelas III Madrasah Ibtidaiyah Karangdowo, Malang. Peneliti melakukan wawancara terbuka terhadap siswa yang telah menerima pelajaran dengan menggunakan media video "AlMutho" untuk mengetahui respon mereka terhadap pembelajaran yang dilakukan oleh peneliti. Sedangkan observasi dilakukan oleh peneliti terhadap siswa untuk mengetahui seberapa berpengaruh media video "Al-Mutho"

${ }^{11}$ Budi Purwanti, 'Pengembangan Media Video Pembelajaran Matematika Dengan Model Assure', Jurnal Kebijakan Dan Pengembangan Pendidikan, 3.1 (2015), 42-47.

${ }^{12}$ Pupu Saeful Rahmat, 'Jurnal-Penelitian-Kualitatif.Pdf', 5 (2009), 18.

${ }^{13}$ Oleh Drg K R Soegijono, 'Wawancara Sebagai Salah Satu Metode Pengumpulan Data', III.01 (1993), 17-21.

${ }^{14}$ Pendidikan D A N Pengajaran, 'Observasi Sebagai Alat Evaluasi Dalam Dunia Pendidikan Dan Pengajaran’, 11.2 (2008), 220-33. 
AL-MUDARRIS:journal of education, Vol. 2. No. 1 April 2019, ISSN: 2620-5831 (print), ISSN: 2620-4355(online)

DOI:

dalam pembelajaran mufrodat kelas 3 Madrasah Ibtidaiyah Karangdowo.

\section{HASIL DAN PEMBAHASAN}

Langkah pertama untuk menentukan kosa kata yang akan dimunculkan dalam video dilakukan telaah kurikulum dan buku ajar kelas III Madrasah Ibtidaiyah. Berikut ini adalah hasil analisis kurikulum kelas III Madrasah Ibtidaiyah pada tabel 1:

Tabel. 1

\begin{tabular}{|c|c|c|}
\hline No & Komponen & Deskripsi \\
\hline 1. & Materi & 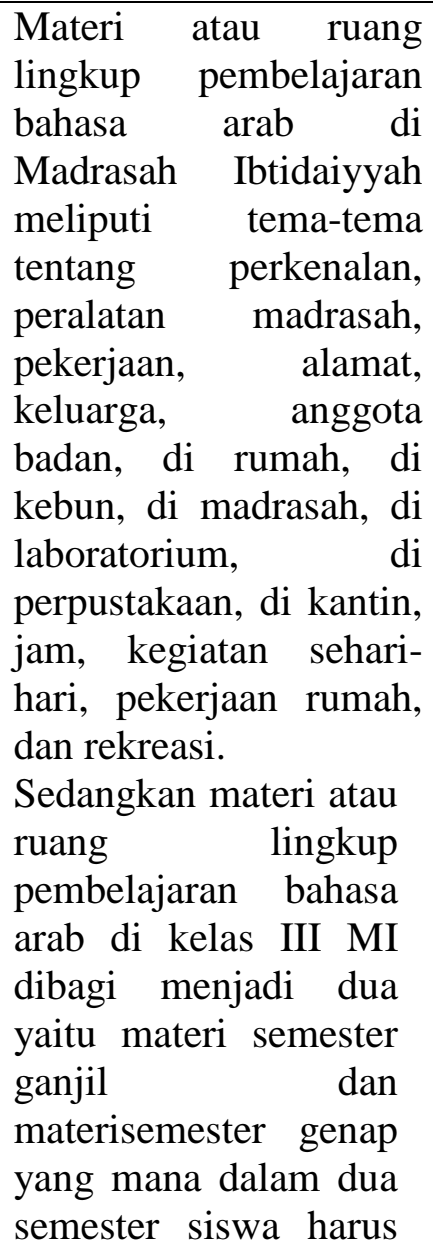 \\
\hline
\end{tabular}


AL-MUDARRIS:journal of education, Vol. 2. No. 1 April 2019, ISSN: 2620-5831 (print), ISSN: 2620-4355(online)

DOI: $10.32478 /$ al-mudarris.v2i1.227

\begin{tabular}{|l|l|}
\hline & menguasai 64-100 \\
& kosa kata Materi \\
semester ganjil yaitu \\
meliputi tema-tema \\
tentang nama-nama \\
pelajaran, \\
anggotawudhu, sholat \\
5 waktu dan nama- \\
nama penyakit. \\
Sedangkan materi \\
pada semester genap \\
yaitu meliputi tema- \\
tema tentang anggota \\
keluarga, sekitar \\
kebun, pemandangan \\
alam, dan nama-nama \\
hewan.
\end{tabular}

Setelah melakukan analisis kurikulum, selanjutnya peneliti melakukan analisis buku ajar kelas III Madrasah Ibtidaiyah. Berikut ini adalah hasil analisis buku ajar kelas III Madrasah Ibtidaiyah dijelaskan pada tabel 2:

Tabel. 2

\begin{tabular}{|l|l|l|}
\hline No & Butir Analisis & Deskripsi \\
\hline 1. & Kecermatan isi & Secara keseluruhan, \\
& & buku ajar ini sudah \\
& memenuhi syarat yang \\
& & sudah ditentukan oleh \\
& ahli kurikulum, yaitu \\
& mencakup semua materi \\
& yang telah dirumuskan. \\
& Masing-masing bab \\
& dalam buku ini telah \\
& menyajikan materi yang \\
& diharapkan dalam \\
& kurikulum maupun \\
& silabus. Pada setiap bab \\
\hline
\end{tabular}


AL-MUDARRIS:journal of education, Vol. 2. No. 1 April 2019, ISSN: 2620-5831 (print), ISSN: 2620-4355(online)

DOI:

\begin{tabular}{|c|c|c|}
\hline & & $\begin{array}{l}\text { dalam buku ini minimal } \\
\text { sudah menyajikan } \\
\text { kosakata berkisar } 8-12 \\
\text { kosa kata. Namun ada } \\
\text { salah satu bab yang } \\
\text { berisi kosakata yang } \\
\text { tidak ada gambarnya, } \\
\text { padahal kosakata lain } \\
\text { terdapat gambar. }\end{array}$ \\
\hline 2. & $\begin{array}{l}\text { Penggunaan } \\
\text { bahasa }\end{array}$ & $\begin{array}{l}\text { Bahasa yang digunakan } \\
\text { dalam buku ajar ini } \\
\text { merupakan bahasa yang } \\
\text { mudah dipahami untuk } \\
\text { siswa kelas III MI. } \\
\text { Dalam setiap bab, buku } \\
\text { ini memberikan kata } \\
\text { perintah yang mudah } \\
\text { dipahami oleh siswa. } \\
\text { Sehingga komunikasi } \\
\text { antara siswa dan guru } \\
\text { bisa berjalan maksimal } \\
\text { karena bahasa dalam } \\
\text { buku ini merupakan } \\
\text { bahasa yang simple dan } \\
\text { mudah dipahami. }\end{array}$ \\
\hline
\end{tabular}

Setelah melakukan analisis kurikulum dan buku ajar, peneliti mulai melakukan proses pembuatan video dengan menggunakan aplikasi Flash Player. Dalam pembuatan video ini peneliti mencantumkan 10 mufrodat yang berkaitan dengan Haalatul Hadiiqoh. Selanjutnya setelah proses pembuatan video ini selesai, peneliti mencoba menerapkan media video "Al-Mutho" pada siswa kelas III MI Karangdowo yang berjumlah 22 siswa. Dalam penerapan video ini peneliti melakukan beberapa langkah, yaitu sebagai berikut:

1. Guru mempersiapkan segala alat yang dibutuhkan seperi laptop, proyektor, pengeras suara dan lain-lain 
2. Guru mempersiapkan media video "Al-Mutho" untuk di mainkan di depan peserta didik

3. Guru mengucapkan salam, mengajak berdoa, bertanya kabar dan mengabsen pesrta didik.

4. Guru memberikan dan menjelas tema pembelajaran yang akan dibahas

5. Guru memberikan atau memainkan video "Al-Mutho" selama dua atau tiga kali agar peserta didik benar-benar bisa mengingat mufrodat yang ada dalam video tersebut.

6. Setelah video habis dan telah diulang selama 2 atau 3 kali, guru memberikan pertanyaan sederhana mengenai mufrodat yang ada dalam video bagi secara lisan maupun tulisan untuk mengukur seberapa berhasil media video "Al-Mutho" dalam meningkatkan kemampuan peserta didik untuk menguasai mufrodat.

7. Guru membuat laporan tentang hasil pembelajaran peserta didik menggunakan media video "Al-Mutho".

Pembelajaran dalam penelitian ini memanfaatkan teknologi dalam pembelajaran bahasa asing untuk siswa. Dalam pembelajaran ini siswa dikenalkan dengan simbolsimbol atau gambar-gambar yang berkaitan dengan Haalatul Hadiiqoh yang sering mereka temui dalam kehidupan sehari-hari berupa bunyi atau suara yang selanjutnya dikembangkan dan digunakan dalam berkomunikasi dengan teman atau orang sekitarnya. ${ }^{15}$

Model pembelajaran dalam penelitian ini menggunakan model Hybrid Learing, yang merupakan pembelajaran yang mengkombinasikan strategi penyampaian pembelajaran menggunakan kegiatan tatap muka (face to face), offline untuk men-download modul dan komputer secara online (forum diskusi/chatting). ${ }^{16}$ Namun pembelajaran dalam penelitian ini menggunakan model 5 dari hybrid learning yang mana model ini adalah model yang paling sederhana dari hybrid learning yaitu siswa dapat mengakses bahanbahan online dari guru meskipun berada di luar kelas. Pada

\footnotetext{
${ }^{15}$ Annisa Rachmani Tyaningsih And Universitas Islam Bandung,
}

'Pembelajaran Bahasa Inggris Pada Siswa Usia Dini', 1990, 74-82.

${ }^{16}$ Berpikir Kritis and others, '1 , 2 , 2 1)', 2013, 1-12. 
DOI:

model ini penggunaan internet di dalam kelas tidak ada, namun guru dan siswa tetap menggunakan pembelajaran tatap muka dengan menggunakan bahan yang tersedia pada sumber internet seperti video. ${ }^{17}$

Hasil penelitian menyatakan bahwa kelas III MI Karangdowo sangat tertarik dan merespon baik terhadap media video "Al-Mutho" pada materi Haalatul Hadiiqoh. Hal ini terlihat dengan sikap siswa yang tenang dan tidak ramai saat diputarkan video "Al-Mutho". Siswa juga menikmati setiap sesi dan meminta utuk diputarkan ulang video "Al-Mutho". Disamping itu video ini juga berisi gambar-gambar kartun yang menarik dan lucu, serta guru di sekolah MI Karangdowo ini juga jarang menggunakan video sebagai pembelajaran meskipun sekolah ini dilengkapi 2 proyektor untuk menunjang proses pembelajaran. Selain itu pembelajaran mufrodat menggunakan video "Al-Mutho" mampu menjadikan siswa lebih aktif dan mampu mengingat lebih banyak kosa kata yang diajarkan. Hal ini terbukti dengan siswa mampu menjawab pertanyaan-pertanyaan sederhana yang diberikan mengenai kosa kata yang diajarkan menggunakan media video "Al-Mutho" diakhir pembelajaran.

\section{E. KESIMPULAN}

Berdasarkan hasil penelitian mengenai hybrid learning dalam pembelajaran kosa kata bahasa arab pada anak berbantuan media Al-Mutho' di Kelas III Madrasah Ibtidaiyah Karangdowo pada materi Haalatul Hadiiqoh diperoleh hasil bahwa video "Al-Mutho" berpengaruh untuk menarik minat siswa dalam belajar dan menghafal kosa kata baru dalam proses pembelajaran bahasa arab. Siswa aktif mengikuti pembelajaran, mampu mengingat kosa kata lebih banyak, dan mampu menjawab pertanyaan yang diberikan. Sehingga dapat disimpulkan bahwa video "Al-Mutho" dikategorikan layak untuk digunakan sebagai media pembelajaran Bahasa Arab.

${ }^{17}$ Ino Angga Putra, 'Orientasi Hybrid Learning Melalui Model Hybrid Learning Dengan’, 1.1 (2015). 
AL-MUDARRIS:journal of education, Vol. 2. No. 1 April 2019, ISSN: 2620-5831 (print), ISSN: 2620-4355(online)

DOI: $10.32478 /$ al-mudarris.v2i1.227

\section{DAFTAR PUSTAKA}

Albantani, Azkia Muharom, Universitas Islam, Negeri Syarif, and Hidayatullah Jakarta, 'OPTIMALISASI APLIKASI BUSUU Arabi: Journal of Arabic Studies', 3 (2018), 1-10

Haryoko, Sapto, 'Efektivitas Pemanfaatan Media Audio-

Visual Sebagai Alternatif Optimalisasi Model

Pembelajaran', Jurnal Edukasi@Elektro, 5 (2010), 110

Kholis, Nur, 'Budayaberbahasaasingdisdlaboratorium Universitas Negeri Malang Kota Blitar', Journal ALMUDARRIS, 1 (2018), 1 <https://doi.org/10.32478/almudarris.v1i1.92>

Kritis, Berpikir, D A N Hasil, Belajar Siswa, and Kelas Xi, '1 , 2, 2 1)', 2013, 1-12

Mahnun, Oleh Nunu, 'MEDIA PEMBELAJARAN ( Kajian Terhadap Langkah-Langkah Pemilihan Media Dan Implementasinya Dalam Pembelajaran )', 37 (2012)

Pengajaran, Pendidikan D A N, 'Observasi Sebagai Alat Evaluasi Dalam Dunia Pendidikan Dan Pengajaran', 11 (2008), 220-33

Pramintya, Devira Wiena, Darlis Herumurti, and Anny Yuniarti, 'Realitas Virtual Untuk Belajar Kosa Kata Bahasa Cardboard', 6 (2017), 402-7

Purwanti, Budi, 'Pengembangan Media Video Pembelajaran

Matematika Dengan Model Assure', Jurnal Kebijakan

Dan Pengembangan Pendidikan, 3 (2015), 42-47

Putra, Ino Angga, 'ORIENTASI HYBRID LEARNING MELALUI MODEL HYBRID LEARNING DENGAN', 1 (2015)

Rahmat, Pupu Saeful, 'Jurnal-Penelitian-Kualitatif.Pdf', 5 (2009), 1-8

Riza Izzatun Nisa', 'Istikhdaamul Wasaailus Sam'iyyatul

Bashoriyyatu "Audio Visual" Litarqiyati Isti'aabil Mufrodaatil 'Arobiyyati Fil Madrosati Miftahul 'Ulum Al-Ibtidaiyah Al-Islamiyah Pasuruan', Skripsi, 2017, $1-102$ 
AL-MUDARRIS:journal of education, Vol. 2. No. 1 April 2019, ISSN: 2620-5831 (print), ISSN: 2620-4355(online)

DOI:

Soegijono, Oleh Drg K R, 'Wawancara Sebagai Salah Satu Metode Pengumpulan Data', III (1993), 17-21

Syaifullah, Muhammad, 'Penguasaan Kosa Kata Bahasa Arab Santri TPA Al-Barokah Hadimulyo Timur Metro Pusat', 11

Tyaningsih, Annisa Rachmani, and Universitas Islam Bandung, 'PEMBELAJARAN BAHASA INGGRIS PADA ANAK USIA DINI', 1990, 74-82

Wahyuddin, 'Ta'limul Lughotil Arobiyyati Bi Thoriiqoti Ta'liimil Mufrodaati (Diroosatun Washfiyyatun Taqwiimiyyatun Fii Jaami'isy Syaikh Nur Jati AlIslaamiyyati Al-Hukuumiyyati Cirebon', 2012, pp. 1152

Wahyudi, Arif, Suhartono, and Ngatman, 'Penggunaan Media Audio Visual', Jurnal Penelitian Pendidikan, 2003

Wekke, Ismail Suardi, MODEL PEMBELAJARAN BAHASA $A R A B$ (Yogyakarta: Deepublish (Group Penerbitan CV BUDI UTAMA), 2015) 